\title{
Michał Sędkowski*
}

\section{Międzynarodowe korporacje w dobie globalnego Internetu - nowa normalność czy zapowiedź kryzysu?}

\begin{abstract}
Abstrakt
Media społecznościowe od wielu lat oferują darmową przestrzeń na dowolne treści stworzone przez użytkowników, jednak dopiero od niedawna padają pytania o faktyczny koszt korzystania z tych usług. Dzięki technologiom internetowym działalność użytkowników w Internecie jest śledzona i przetwarzana do celów marketingowych, bardzo często bez możliwości zatrzymania czy ograniczenia tego procesu. Problem ten okazał się szczególnie istotny w czasie pandemii, gdzie Internet stał się jedynym źródłem informacji oraz narzędziem komunikacji z innymi. Autor artykułu stawia hipotezę badawczą, że użytkownicy mają bardzo ograniczony zakres kontroli nad swoimi danymi w Internecie, a państwowe agendy nie posiadają odpowiednich narzędzi, by wymusić realną w tym zakresie. Przeprowadzona analiza źródeł potwierdziła tę hipotezę, wskazując na bezradność Unii Europejskiej oraz Stanów Zjednoczonych w zakresie realnego oddziaływania na globalne korporacje.
\end{abstract}

Słowa kluczowe: korporacja, globalizacja, kryzys, marketing, prywatność, media społecznościowe.

International corporations in the age of the global Internet - new normality or a harbinger of a crisis?

\section{Abstract}

For many years, social media has offered free space for any user-created content, but only recently have questions been asked about the actual cost of using these services. Thanks to Internet technologies, the activity of users on the Internet is tracked and processed for

Adiunkt, politolog, Uniwersytet Łódzki, Wydział Studiów Międzynarodowych i Politologicznych, Katedra Marketingu Międzynarodowego i Dystrybucji; e-mail: michal. sedkowski@uni.lodz.pl 
marketing purposes, very often without the possibility of stopping or limiting this process. This problem turned out to be particularly important during the pandemic, where the Internet became the only source of information and a tool for communication with others. The author of the article puts forward a research hypothesis that users have a very limited scope of control over their data on the Internet, and state agencies do not have the appropriate tools to force a real change in this regard. The conducted analysis of sources confirmed this hypothesis, pointing to a weakness of the European Union and the United States in terms of real impact on global corporations.

Keywords: corporation, globalization, crisis, marketing, privacy, social media.

\section{Wprowadzenie}

Pandemia koronawirusa spowodowała drastyczne zmiany w sposobie funkcjonowania gospodarek Państw na całym świecie. Niemalże z dnia na dzień instytucje rządowe, firmy czy instytucje edukacyjne musiały przestawić się z tradycyjnej pracy biurowej, bazującej na kontaktach bezpośrednich, na pracę zdalną. Ta forma działalności istniała oczywiście wcześniej, jednak jak podaje serwis Statista ${ }^{1}$, 47\% amerykańskich pracowników nie zetknęło się z pracą zdalną przed pandemią. Podobnie statystyki wyglądają w krajach Unii Europejskiej, gdzie ponad połowa osób pracujących ${ }^{2}$ deklarowała, że nie zetknęła się wcześniej z taką formą świadczenia pracy. Dane te pokazują, że została wykonana ogromna praca, by przygotować pracowników oraz niezbędny sprzęt do pracy w nowych warunkach. Firmy Google ${ }^{3}$, Microsoft $^{4}$ czy Zoom ${ }^{5}$ zanotowały rekordowy przyrost użytkowników w roku 2020, co przełożyło się na dobre wyniki finansowe. Pandemia spowodowała przyspieszenie procesów, które obserwowane były w gospodarce światowej od wielu

1 Change in remote work trends due to COVID-19 in the United States in 2020, "Statista”, https://www.statista.com/statistics/1122987/change-in-remote-work-trends-after-covid-in-usa/ (dostęp: 8.07.2021).

2 Telework in the EU before and after the COVID-19: where we were, where we head to, „Science for Policy Briefs”, https://ec.europa.eu/jrc/sites/default/files/jrc120945_policy_brief_-_covid_and_telework_final.pdf (dostęp: 8.07.2021).

3 M. Grzegorzewska, Miliard czy milion - liczba użytkowników Google, „SternaSEO”, https:// sternaseo.pl/miliard-czy-milion-liczba-uzytkownikow-google/ (dostęp: 8.07.2021).

4 K. Slikowski, Microsoft Teams ma już 145 milionów aktywnych użytkowników dziennie, „CentrumXP”, https://www.centrumxp.pl/Publikacja/Microsoft-Teams-ma-juz-145-milionow-aktywnych-uzytkownikow-dziennie (dostęp: 8.07.2021).

5 M. Żuławiński, Zoom przeżywa boom. Wideokonferencje warte więcej niż linie lotnicze, „Bankier.pl”, https://www.bankier.pl/wiadomosc/Zoom-przezywa-boom-Wideokonferencje-warte-wiecej-niz-linie-lotnicze-7886776.html (dostęp: 8.07.2021). 
lat. Coraz więcej usług w sektorze publicznym i prywatnym jest dostępne przez Internet, który od początku pandemii stał się czymś więcej niż nośnikiem komunikacyjnym. Życie zawodowe oraz prywatne wielu osób przeniosło się do Internetu, a wideokonferencje stały się codziennością. Fakt ten można interpretować na dwa sposoby: $\mathrm{z}$ jednej strony przeniesienie wielu aspektów życia zawodowego i prywatnego do sieci globalnej umożliwiło wielu osobom pracę i utrzymanie kontaktów społecznych pomimo braku możliwości fizycznego wyjścia do pracy czy spotkania się z rodziną. $Z$ drugiej strony, aktywność użytkowników w Internecie jest rejestrowana, a wprowadzane dane wykorzystywane do celów marketingowych. Wideokonferencje, rozmowy tekstowe czy głosowe są stale monitorowane i analizowane, a zebrane w ten sposób dane przechowywane przez wiele miesięcy, a nawet lat. Należy postawić tu pytanie o przyszłość komunikacji i pracy zdalnej w zglobalizowanym świecie, gdzie korporacje dostarczają podstawowe narzędzia i infrastrukturę, w zamian oczekując dostępu do danych użytkowników, które są wykorzystywane do poprawy jakości produktów, ale także do celów marketingowych oraz profilowania. Celem niniejszego rozdziału jest spojrzenie na potencjalne korzyści i zagrożenia dla użytkowników Internetu, wynikające z korzystania z popularnych, darmowych narzędzi do komunikacji przez globalną sieć. Szczególnie nacisk położono na firmę Facebook oraz Google jako przykład dwóch globalnych korporacji, których model biznesowy jest podobny, a użytkownicy płacą swoimi danymi za oferowane usługi.

\section{Transformacja cyfrowa w dobie pandemii}

Początek roku 2020 nie odbiegał od wielu poprzednich. Międzynarodowe korporacje ogłaszały swoje wyniki finansowe, budując przy tym narrację nakierowaną na utrzymanie zainteresowania ich produktami i usługami wśród konsumentów. Jednak już 30 stycznia W.H.O ${ }^{6}$ ogłosiła stan wyjątkowy, a z końcem marca większość krajów wprowadza różnego rodzaju obostrzenia mające na celu zatrzymać rozprzestrzenianie się wirusa. Restrykcje te zwykle dotyczyły swobody poruszania się, podróży oraz działalności (lub całkowitego zawieszenia) niektórych gałęzi gospodarki. Efektem tych zmian było przejście wielu podmiotów publicznych i prywatnych na działalność przez Internet oraz telefon. Spowodowało to znaczące zmiany w ilości użytkowników, którzy zaczęli codziennie korzystać z rozwiązań telekomunikacyjnych, by wykonywać swoje obowiązki służbowe, uczyć się lub po prostu

6 D. B. Taylor, A Timeline of the Coronavirus Pandemic, „New York Times”, https://www. nytimes.com/article/coronavirus-timeline.html (dostęp: 9.07.2021). 
utrzymywać kontakty z bliskimi. W Stanach Zjednoczonych już w połowie marca 2020 r. zaobserwowano wzrost o 25\% liczby użytkowników, którzy korzystali z Internetu codziennie ${ }^{7}$. W kwietniu 2020 r. zanotowano największy skok ilości danych, jaka była transmitowana przez gospodarstwa domowe ${ }^{8}$. Szacuje się, że wzrost ten wyniósł około 36\%. Fenomen ten można wyjaśnić wspomnianymi obostrzeniami, wprowadzanymi przez poszczególne kraje, co niejako zmusiło społeczeństwa do poszukiwania innych metod pracy oraz źródeł rozrywki. Warto przy tym podkreślić, że nie zwiększyła się znacząco liczba użytkowników Internetu jako takich. Pandemia spowodowała, że osoby, które posiadały dostęp do Internetu, korzystały z niego dłużej i częściej, co przełożyło się na wzrost liczby transmitowanych danych ${ }^{9}$. Sytuacja w Polsce wyglądała bardzo podobnie. Według danych Głównego Urzędu Statystycznego za rok 2020 dostęp do szerokopasmowego Internetu miało w Polsce $90,4 \%$ gospodarstw domowych, co stanowi wzrost o $4 \%$ rok do roku ${ }^{10}$. Raport ten wskazuje także, że Internet był najpopularniejszym źródeł informacji o koronawirusie. 90,3\% Polaków poszukiwało informacji na ten temat na stronach internetowych, zaś $68 \% \mathrm{w}$ mediach społecznościowych ${ }^{11}$. Najwyższy odsetek osób korzystających z Internetu notuje się w grupie wiekowej 18-34 lat i wynosi ponad $95 \%{ }^{12}$. Statystyki te wyraźnie pokazują, że dostęp do Internetu w Polsce przestaje być problemem, choć około $10 \%$ społeczeństwa jest zagrożona wykluczeniem cyfrowym, co stanowi dość istotne wyzwanie. Ilość przesyłanych danych, podobnie jak w Stanach Zjednoczonych, gwałtownie wzrosła na początku pandemii, jednak na rynku polskim brakuje jednoznacznych statystyk w tym zakresie. Szacuje się, że wzrost ten wynosił

7 L. Rizzo, S. Click, How Covid-19 Changed Americans' Internet Habits, „The Wall Street Journal", https://www.wsj.com/articles/coronavirus-lockdown-tested-internets-backbone-11597503600 (dostęp: 11.07.2021).

8 C. Ang, One Year in: Data Usage Surged During Pandemic, „Visual Capitalist”, https:// www.visualcapitalist.com/data-usage-surged-during-pandemic/ (dostęp: 12.07.2021).

9 OECD, Digital Transformation in the Age of COVID-19: Building Resilience and Bridging Divides, „Digital Economy Outlook 2020 Supplement”, www.oecd.org/digital/digital-economy-outlook-covid.pdf (dostęp: 11.07.2021).

10 Społeczeństwo informacyjne w Polsce w 2020 r., „Główny Urząd Statystyczny”, https:// stat.gov.pl/download/gfx/portalinformacyjny/pl/defaultaktualnosci/5497/2/10/1/spoleczenstwo_informacyjne_w_polsce_w_2020.pdf (dostęp: 11.07.2021).

11 GUS: w 2020 r. Internet najpopularniejszym źródłem informacji o COVID-19, „Polsat News", https://www.polsatnews.pl/wiadomosc/2021-03-11/gus-w-2020-r-internet-najpopularniejszym-zrodlem-informacji-o-covid-19/ (dostęp: 11.07.2021).

12 Korzystanie $z$ internetu. Komunikat $z$ badań, CBOS, https://www.cbos.pl/SPISKOM. POL/2020/K_085_20.PDF (dostęp: 13.07.2021). 
około $40 \%$ względem roku $2019^{13}$, bazując na wartościach podanych przez operatorów sieci komórkowych. Statystyczny użytkownik Internetu w Polsce aktywnie korzysta $\mathrm{z}$ tego medium przez prawie 7 godzin dziennie ${ }^{14}$. Polscy użytkownicy Internetu najwięcej czasu spędzają, korzystając z różnego rodzaju serwisów umożliwiających oglądanie treści (streaming services) oraz serwisów społecznościowych. Istotnym elementem jest także poszukiwanie i konsumowanie wiadomości w Internecie, w tym informacji na temat koronawirusa. Nie będzie przesadą stwierdzenie, że Internet stał się dla statystycznego obywatela Polski podstawowym źródłem treści.

Tabela 1. Wykorzystanie Internetu w Polsce w 2020 r.

\begin{tabular}{|l|c|}
\hline \multicolumn{1}{|c|}{ Aktywność w Internecie } & Czas (codziennie) \\
\hline Łączny czas spędzony w Internecie & 6 godzin 44 minuty \\
\hline Oglądanie telewizji (na żywo i na żądanie) & 3 godziny 16 minut \\
\hline Media społecznościowe & 1 godzina 59 minut \\
\hline Czytanie wiadomości prasowych & 1 godzina 16 minut \\
\hline Słuchanie muzyki na żądanie & 1 godzina 10 minut \\
\hline Słuchanie radia na żywo & 1 godzina 51 minut \\
\hline Słuchanie podcastów & 36 minut \\
\hline Gry komputerowe (za pomocą konsoli do gier) & 43 minuty \\
\hline
\end{tabular}

Źródło: opracowanie własne na podstawie: S. Kemp, Digital 2021: Poland, https://datareportal. com/reports/digital-2021-poland?rq=poland (dostęp: 13.07.2021).

Warto przy tym podkreślić, że przytoczone w tabeli 1 dane są bardzo zbliżone do wartości z innych krajów ${ }^{15}$. Oznacza to, że Polacy bardzo chętnie korzystają z usług multimedialnych oferowanych przez Internet i choć istnieje nadal grupa osób zagrożonych cyfrowym wykluczeniem, znakomita większość społeczeństwa posiada stały dostęp do Internetu. Pandemia przyspieszyła trwające od wielu lat procesy, gdzie aktywność społeczeństw w świecie cyfrowym stale rosła. Media społecznościowe stały się pewnym katalizatorem,

13 W. Piechocki, Polskie sieci komórkowe obsługuja rekordowe ilości przesyłanych danych - jesteśmy w europejskiej czołówce, „GSMOnline.pl”, https://gsmonline.pl/artykuly/ruch-danych-sieci-komorkowe-europa-polska (dostęp: 13.07.2021).

14 Jak Polacy korzystaja $z$ internetu? Oto raport $z 2021$ roku!, „Funkymedia”, https://funkymedia.pl/jak-polacy-korzystaja-z-internetu-oto-raport-z-2021-roku.html (dostęp: 13.07.2021).

15 Digital 2021. We are social, https://wearesocial.com/digital-2021 (dostęp: 13.07.2021). 
oferującym zwykłym użytkownikom możliwość zaprezentowania własnych myśli, przekonań czy twórczości bez konieczności posiadania wiedzy technicznej koniecznej do uruchomienia własnej strony internetowej. Niestety okazało się, że media społecznościowe oferują wprawdzie szeroki dostęp do nowych treści, jednak te materiały podlegają ścisłej kontroli algorytmów mających pokazać użytkownikowi jedynie pewien wycinek rzeczywistości. Stwierdzenie to nie jest niczym nowym, jednak jest ono szczególnie niepokojące w obliczu pandemii, gdzie Internet i media społecznościowe stały się dla wielu osób jedynym oknem na świat.

\section{Media społecznościowe na świecie i w Polsce}

Media społecznościowe to serwisy internetowe pozwalające użytkownikom komunikować się z innymi ${ }^{16}$. Ta definicja już dawno przestała w pełni oddawać ideę i funkcjonalność oferowaną przez media społecznościowe, jednak stanowi ona dobry punkt wyjścia do dalszych rozważań. Nim pojawiły się media społecznościowe, publikowanie w Internecie wymagało wiedzy technicznej. Stworzenie własnej strony internetowej wymagało znajomości odpowiedniego języka programowania, a koszt wynajęcia przestrzeni na serwerze był relatywnie wysoki, zwłaszcza jeśli ktoś tworzył witrynę do celów prywatnych. Istniejące w Internecie fora czy blogi zwykle skupiały się na konkretnej tematyce, stąd użytkownik, który chciał dyskutować na kilka tematów jednocześnie, musiał znaleźć i dołączyć do kilku takich internetowych wspólnot ${ }^{17}$. Wymagało to od wspomnianego użytkownika wykonania pewnej dodatkowej pracy i czasu, aby dotrzeć do interesujących go treści i śledzić na bieżąco trwające tam dyskusje. Media społecznościowe oferują zupełnie odmienne podejście, gdzie treści są umieszczane bezpośrednio na profilu użytkownika i wszystkie działania wykonywane są w ramach jednej strony internetowej ${ }^{18}$. Co istotne, oferowane przez serwis narzędzia do tworzenia treści (postów) są zwykle bardzo zbliżone do standardowych edytorów tekstu, przez co są łatwe w użyciu dla zwykłego użytkownika ${ }^{19}$. Nie jest konieczna specjalistyczna wiedza czy oprogramowanie. W początkowym okresie media społecznościowe były nastawione na korzystanie z ich zasobów za pośrednictwem komputera

16 D. Miller, E. Costa, T. McDonald, R. Nicolescu, J. Sinanan, J. Spyer, S. Venkatraman,

X. Wang, How the World Changed Social Media, London 2016, s. 9.

17 D. Jemielniak, Socjologia internetu, Warszawa 2019, s. 36.

18 M. Miller, Facebook for Grown-ups, Hoboken 2010, s. 126.

19 A. M. Kaplan, M. Haenlein, Users of the World, Unite! The Challenges and Opportunities of Social Media, „Business Horizons” 2010, t. 53. 
stacjonarnego i przeglądarki internetowej. Z czasem punkt ciężkości został przeniesiony na smartfony ${ }^{20}$ i aplikacje dedykowane poszczególnym serwisom. Media społecznościowe bardzo szybko zdobyły popularność, zwłaszcza wśród młodych użytkowników, oferując możliwość natychmiastowej wymiany myśli i treści z innymi. W 2004 r. zostaje uruchomiony Facebook - obecnie najpopularniejsza platforma społecznościowa. Dominacja tego serwisu na rynku trwa nieprzerwanie od 2008 r., kiedy liczba unikatowych użytkowników na stronie przekroczyła 115 milionów miesięcznie ${ }^{21}$. Przyczyn sukcesu Facebook z punktu widzenia atrakcyjności dla użytkownika należy doszukiwać się w kilku aspektach (tabela 2).

Tabela 2. Sukces Facebooka jako platformy społecznościowej

\begin{tabular}{|l|l|}
\hline \multicolumn{1}{|c|}{ Element serwisu } & \multicolumn{1}{c|}{ Komentarz } \\
\hline Dostępność & $\begin{array}{l}\text { Serwis jest dostępny za pośrednictwem przeglądarki internetowej, } \\
\text { bez konieczności instalowania dodatkowego oprogramowania. }\end{array}$ \\
\hline Uniwersalność & $\begin{array}{l}\text { Serwis jest dostępny na wszystkich platformach mobilnych oraz } \\
\text { stacjonarnych. Dedykowane aplikacje na urządzenia mobilne są } \\
\text { spójne wizualnie i zbliżone wyglądem do strony internetowej. }\end{array}$ \\
\hline $\begin{array}{l}\text { Nieograniczona prze- } \\
\text { strzeń na dane }\end{array}$ & $\begin{array}{l}\text { Facebook w żaden sposób nie ogranicza liczby zdjęć czy postów, } \\
\text { jakie może zamieścić użytkownik. Materiały te są zawsze dostępne } \\
\text { i nigdy nie są usuwane. }\end{array}$ \\
\hline Interaktywność & $\begin{array}{l}\text { Serwis oferuje możliwość szybkiego zareagowania na opublikowa- } \\
\text { ne treści poprzez emotikon czy udostępnienie dalej. Nawet osoba, } \\
\text { która sama nie chce nic tworzyć, może w ten sposób dołączyć do } \\
\text { dyskusji. }\end{array}$ \\
\hline $\begin{array}{l}\text { Nieskończone źródło } \\
\text { treści }\end{array}$ & $\begin{array}{l}\text { Facebook stale proponuje swoim użytkownikom nowe treści, znajo- } \\
\text { mych czy instytucje do obserwowania. Przy każdym logowaniu użyt- } \\
\text { kownik otrzymuje nowy strumień danych, który nigdy się nie kończy. }\end{array}$ \\
\hline $\begin{array}{l}\text { Możliwość łatwego } \\
\text { znalezienia nowych } \\
\text { kontaktów }\end{array}$ & $\begin{array}{l}\text { Platforma dysponuje obecnie największą liczbą użytkowników, } \\
\text { stąd szansa na odszukanie konkretnej osoby jest bardzo wysoka. }\end{array}$ \\
\hline Brak opłat & $\begin{array}{l}\text { Użytkownicy nie muszą wnosić żadnych opłat za korzystanie z ser- } \\
\text { wisu. }\end{array}$ \\
\hline
\end{tabular}

Źródło: opracowanie własne.

20 M. De Saulles, The Internet of Things and Business, New York 2017, s. 34.

21 M. Arrington, Facebook No Longer The Second Largest Social Network, „TechCrunch”, https://techcrunch.com/2008/06/12/facebook-no-longer-the-second-largest-social-network/ (dostęp: 13.07.2021). 
Facebook od początku swojego istnienia pozycjonował się jako platforma skierowana do wszystkich użytkowników, niezależnie od ich potrzeb czy zainteresowań. Sieć akceptowała w zasadzie dowolne treści, kładąc przy tym nacisk na ich multimedialność. Zdjęcia, filmy czy krótkie teksty nasycone emotikonami były i są atrakcyjne wizualnie, przyciągają wzrok i uwagę odwiedzających. Jednocześnie firma stale rozwijała zakres oferowanych usług: w 2008 r. wprowadzono usługę Messenger - czat błyskawiczny, zaś trzy lata później usługa zadebiutowała jako odrębna aplikacja ${ }^{22}$. W roku 2012 firma kupiła Instagram ${ }^{23}$, sieć społecznościową nastawioną na publikowanie i komentowanie fotografii. Facebook słusznie przewidział, że wzrost zainteresowania smartfonami - urządzeniami z wbudowanym aparatem fotograficznym spowoduje wzrost zainteresowania tą formą komunikowania się. Kluczowa okazała się także kolejna inwestycja z 2014 r. - zakup komunikatora WhatsApp ${ }^{24}$. Aplikacja pozwala na darmową komunikację pomiędzy użytkownikami, minimalizując przy tym koszty związane z użyciem danych, co przełożyło się na dużą popularność serwisu w krajach rozwijających się, gdzie koszty usług mobilnych są relatywnie wysokie, a dostęp do sieci ograniczony. Efektem tych działań jest wytworzenie się swoistego ekosystemu ${ }^{25}$ wokół Facebooka, gdzie oferowane usługi są względem siebie komplementarne. Użytkownicy otrzymują pakiet narzędzi komunikacyjnych pozwalający przesyłać wiadomości skierowane do pojedynczych osób, jak również szerszych grup. Stanowi to silną przewagę konkurencyjną tej platformy, trudną do powielenia przez konkurencję. Statystyki jasno wskazują ${ }^{26}$, że Facebook jest dominującym graczem na rynku mediów społecznościowych, zajmując ponad $70 \%$ rynku w czerwcu 2021 r. Najpopularniejsi konkurenci pod względem liczby użytkowników - Twitter i Pinterest mają odpowiednio nieco ponad 10\% i 7\%. Trudno więc tu doszukiwać się realnej konkurencji, zwłaszcza że wspomniane serwisy mają znacznie węższą grupę docelową. Twitter jest nakiero-

22 J. Kincaid, Facebook Launches Standalone iPhone/Android Messenger App, „TechCrunch”, https://techcrunch.com/2011/08/09/facebook-launches-standalone-mobile-messenger-app-and-it\%E2\%80\%99s-beluga/ (dostęp: 13.07.2021).

23 S. Rodriguez, As Calls Grow to Split up Facebook, Employees Who Were There for the Instagram Acquisition Explain Why the Deal Happened, CNBC, https://www.cnbc. com/2019/09/24/facebook-bought-instagram-because-it-was-scared-of-twitter-and-google.html (dostęp: 13.07.2021).

24 A. L. Deutsch, WhatsApp: The Best Facebook Purchase Ever?, „Investopedia”, https:// www.investopedia.com/articles/investing/032515/whatsapp-best-facebook-purchase-ever.asp (dostęp: 13.07.2021).

25 T. Blanke, Digital Asset Ecosystems: Rethinking Crowds and Clouds, Kidlington 2014, s. 23.

26 Social Media Stats Worldwide, „Statcounter. GlobalStats”, https://gs.statcounter.com/social-media-stats (dostęp: 13.07.2021). 
wany na szybkość przesyłania informacji, a wiadomości są bardzo krótkie i pozbawione multimediów ${ }^{27}$. Pinterest natomiast to wizualna wyszukiwarka pomysłów ${ }^{28}$. Dominują tu raczej zdjęcia i kolaże, komunikacja bezpośrednia odgrywa mniejsze znaczenie. Portale te nie mają możliwości zagrozić dominacji Facebooka, ponieważ są nakierowane na zupełnie inną grupę odbiorców i specjalizują się w dostarczaniu innego typu treści. W Polsce sytuacja na rynku mediów społecznościowych wygląda nieco inaczej ${ }^{29}$. Liderem jest oferowany przez firmę Google serwis YouTube, z którego korzysta ponad $90 \%$ internautów. Kolejne 4 miejsca w rankingu zajmują produkty oferowane przez firmę Facebook: serwis społecznościowy pod tą samą nazwą $(89,2 \%)$, Messenger (76,5\%), Instagram (60,8\%) i WhatsApp (48,2\%). Dopiero na 6 pozycji plasuje się Twitter, z którego korzysta 37,5\% polskich internautów. Te dane pokazują, że marka Facebook jest bardzo silna i skutecznie opanowała rynek mediów społecznościowych, także w Polsce. W tym miejscu warto postawić pytanie o konsekwencje tak silnej pozycji dominującego podmiotu na rynku oraz o możliwe negatywne skutki takiego stanu rzeczy. Firma Facebook na swojej oficjalnej stronie internetowej określa swoją misję ${ }^{30}$ następująco: „Dać ludziom siłę do budowy wspólnoty oraz zbliżyć świat do siebie” 31 . Jest to bardzo szczytny cel, jednak misja firmy jest niewystarczająca, aby mogła skutecznie konkurować na rynku. Należy postawić pytanie o źródło dochodów - w jaki sposób są generowane przychody, jeżeli znakomita większość usług oferowanych konsumentom jest całkowicie darmowa?

\section{Globalny Internet jako cyfrowa kopalnia danych}

Facebook, podobnie jak wiele innych platform społecznościowych, utrzymuje się z reklam, jakie wyświetlane są na portalu. Firma w pewnym uproszczeniu oferuje dwie podstawowe usługi: platformę społecznościową

27 J. Burgess, N. K. Baym, Twitter: A Biography, New York 2020, s. 15.

${ }_{28}$ Wszystko o Pintereście, https://help.pinterest.com/pl/guide/all-about-pinterest (dostęp: 13.07.2021).

29 S. Kemp, Digital 2021: Poland, https://datareportal.com/reports/digital=2021--poland?rqpoland (dostęp: 13.07.2021).

30 Misja firmy to pewnego rodzaju dalekosiężny cel, rola organizacji w jej otoczeniu, akcentujący jej potrzebę istnienia. Cel ten powinien stanowić pewnego rodzaju ogólny kierunek rozwoju organizacji lub firmy. I. Penc-Pietrzak, Planowanie strategiczne w nowoczesnej firmie, Warszawa 2010, s. 45.

31 Tłumaczenie własne na podstawie oficjalnej strony firmy Facebook, https://about.facebook.com/company-info/ (dostęp: 14.07.2021). 
(komunikacyjną) i platformę reklamową. Pierwsza jest oferowana za darmo, druga zaś wymaga wnoszenia opłaty. To co odróżnia Facebooka od innych firm reklamowych, to dostęp do danych i możliwość profilowania użytkowników. Facebook oraz produkty zależne - Messenger, Instagram oraz WhatsApp wykorzystują wszelkie dane wprowadzone przez użytkownika do stworzenia jego profilu. Profil ten jest tworzony na podstawie aktywności użytkownika na samym portalu, jak również w aplikacjach mobilnych oraz na innych stronach internetowych ${ }^{32}$. Wiele stron internetowych w Internecie zawiera obecnie mały fragment kodu ${ }^{33}$, który identyfikuje użytkownika, i jeżeli ten jest zalogowany na Facebooku, automatycznie łączy te dane z jego profilem. Serwis w ten sposób jest w stanie śledzić działalność użytkownika, nie tylko w ramach serwisu, lecz także poza nim ${ }^{34}$. Innymi słowy im więcej danych Facebook jest w stanie zebrać na temat swoich użytkowników, tym dokładniejszy i bardziej szczegółowy staje się ich profil. To zaś pozwala zaoferować reklamodawcom niespotykane dotąd możliwości w zakresie personalizacji reklam. Podstawowym wyzwaniem współczesnego marketingu jest dotarcie z przekazem do osób, które są zainteresowane danym produktem czy usługą. Marketing masowy jest nieefektywny, a konsumenci nauczyli się ignorować typowe przekazy reklamowe ${ }^{35}$. Marketing internetowy bazuje na zdobyciu jak najdokładniejszych informacji na temat danego użytkownika, aby wiadomość reklamowa miała spersonalizowany charakter i tym samym większe szanse na wywołanie pożądanej reakcji ${ }^{36}$. Zbieranie wartościowych danych na temat konsumentów to proces bardzo długotrwały i kosztowny. Badania marketingowe zawsze narażone są na różnego rodzaju błędy wynikające zarówno $\mathrm{z}$ samego procesu badawczego ${ }^{37}$ oraz niechęci ze strony respondentów do udzielania prawdziwych odpowiedzi. Na Facebooku to sami użytkownicy dostarczają algorytmom informacji na swój temat poprzez

32 K. O'Flaherty, All the Ways Facebook Tracks You and How to Stop It, „Forbes”, https:// www.forbes.com/sites/kateoflahertyuk/2021/05/08/all-the-ways-facebook-tracks-you-and-how-to-stop-it/ (dostęp: 16.07.2021).

33 Piksel Facebooka, Facebook for Business, https://www.facebook.com/business/help/7424 78679120153 ? id=1205376682832142 (dostęp: 16.07.2021).

34 A. Hutchinson, What Does Facebook Know About You Really?, „Social Media Today”, https://www.socialmediatoday.com/news/what-does-facebook-know-about-you-really/546502/ (dostęp: 16.07.2021).

35 T. Osenton, Customer Share Marketing: How the World's Great Marketers Unlock Profits from Customer Loyalty, New Jersey 2002, s. 46.

36 V. Kumar, W. Reinartz, Customer Relationship Management: Concept, Strategy, and Tools, Bamberg 2018, s. 159.

37 R. Grover, M. Vriens, The Handbook of Marketing Research: Uses, Misuses, and Future Advances, London 2006, s. 161. 
wstawianie nowych postów, zdjęć czy wchodzeniu $\mathrm{w}$ interakcje $\mathrm{z}$ treściami zamieszczonymi przez innych użytkowników portalu. Algorytmy te tworzą mapę połączeń i interakcji konkretnego użytkownika portalu z innymi, co pozwala na zbudowanie bardzo dokładnego profilu takiej osoby. Prawdopodobieństwo wystąpienia błędu naturalnie istnieje, ale jest znikome. Podsumować te rozważania można następująco: im większą ilością danych Facebook dysponuje na temat konkretnej osoby, tym reklamy wyświetlane takiej osobie stają się bardziej spersonalizowane, a zyski z ich sprzedaży rosną. Konsument otrzymuje darmowy, pełnowartościowy produkt, a portal społecznościowy nieograniczony dostęp do danych swoich użytkowników.

Tabela 3. Potencjalne korzyści dla użytkownika i portalu społecznościowego

\begin{tabular}{|c|c|c|c|}
\hline $\begin{array}{l}\text { Element } \\
\text { serwisu }\end{array}$ & $\begin{array}{l}\text { Korzyść dla } \\
\text { użytkownika }\end{array}$ & $\begin{array}{l}\text { Korzyść dla serwisu } \\
\text { społecznościowego }\end{array}$ & Komentarz \\
\hline Dostępność & $\begin{array}{l}\text { Możliwość korzystania } \\
\text { z usługi, niezależnie od } \\
\text { miejsca czy użytkowa- } \\
\text { nego urządzenia. }\end{array}$ & $\begin{array}{l}\text { Dostępność dla moż- } \\
\text { liwie najszerszej grupy } \\
\text { docelowej. }\end{array}$ & $\begin{array}{l}\text { Użytkownik otrzymuje } \\
\text { rozwiązanie komu- } \\
\text { nikacyjne dostępne } \\
\text { zawsze i w każdym } \\
\text { miejscu, co zniechęca } \\
\text { do poszukiwania alter- } \\
\text { natyw. }\end{array}$ \\
\hline Uniwersalność & $\begin{array}{l}\text { Wygląd i obsługa ser- } \\
\text { wisu są praktycznie } \\
\text { identyczne na każ- } \\
\text { dym urządzeniu, co } \\
\text { ułatwia opanowanie } \\
\text { obsługi poszczegól- } \\
\text { nych funkcji. }\end{array}$ & $\begin{array}{l}\text { Marka serwisu jest } \\
\text { widoczna i łatwo roz- } \\
\text { poznawalna. Proces } \\
\text { wprowadzania zmian } \\
\text { i nowych funkcji jest } \\
\text { szybszy i prostszy. }\end{array}$ & - \\
\hline $\begin{array}{l}\text { Nieograniczona } \\
\text { przestrzeń na } \\
\text { dane }\end{array}$ & $\begin{array}{l}\text { Użytkownik otrzymuje } \\
\text { nieograniczoną prze- } \\
\text { strzeń na swoje posty } \\
\text { i inne materiały; może } \\
\text { prowadzić swego ro- } \\
\text { dzaju pamiętnik. }\end{array}$ & $\begin{array}{l}\text { Serwis otrzymuje do- } \\
\text { stęp do wszelkich } \\
\text { materiałów opubliko- } \\
\text { wanych przez użyt- } \\
\text { kownika, które są nie- } \\
\text { ocenionym źródłem } \\
\text { wiedzy, niezbędnym } \\
\text { do przeprowadzenia } \\
\text { dogłębnego profilowa- } \\
\text { nia użytkownika. }\end{array}$ & $\begin{array}{l}\text { Udostępnianie mate- } \\
\text { riałów na platformie } \\
\text { społecznościowej ma } \\
\text { charakter naturalny, } \\
\text { stąd użytkownicy chęt- } \\
\text { niej dzielą się swoimi } \\
\text { przemyśleniami, czę- } \\
\text { sto działając pod wpły- } \\
\text { wem emocji. }\end{array}$ \\
\hline
\end{tabular}


Tabela 3 (cd.)

\begin{tabular}{|c|c|c|c|}
\hline $\begin{array}{l}\text { Element } \\
\text { serwisu }\end{array}$ & $\begin{array}{l}\text { Korzyść dla } \\
\text { użytkownika }\end{array}$ & $\begin{array}{l}\text { Korzyść dla serwisu } \\
\text { społecznościowego }\end{array}$ & Komentarz \\
\hline Interaktywność & $\begin{array}{l}\text { Użytkownik może do- } \\
\text { łączyć do dyskusji po- } \\
\text { przez udostępnienie } \\
\text { materiału dalej, napi- } \\
\text { sanie komentarza czy } \\
\text { kliknięciu emotikonu. } \\
\text { Nawet osoby, które } \\
\text { nie chcą samodzielnie } \\
\text { tworzyć nowych treści, } \\
\text { mogą stać się częścią } \\
\text { społeczności. }\end{array}$ & $\begin{array}{l}\text { Sieć społecznościowa } \\
\text { buduje w ten sposób } \\
\text { sieć powiązań między } \\
\text { użytkownikami, może } \\
\text { je badać i mierzyć, } \\
\text { które treści wywołują } \\
\text { reakcję wśród użyt- } \\
\text { kowników. }\end{array}$ & $\begin{array}{l}\text { Z punktu widzenia sie- } \\
\text { ci społecznościowej } \\
\text { wartościowa informa- } \\
\text { cja to taka, która wy- } \\
\text { woła reakcję, zatrzyma } \\
\text { użytkownika przed } \\
\text { ekranem. }\end{array}$ \\
\hline $\begin{array}{l}\text { Nieskończone } \\
\text { źródło treści }\end{array}$ & $\begin{array}{l}\text { Użytkownik stale } \\
\text { otrzymuje dostęp do } \\
\text { nowych treści i propo- } \\
\text { zycji, kogo obserwo- } \\
\text { wać. Powstaje w ten } \\
\text { sposób kanał infor- } \\
\text { macyjny, który zawsze } \\
\text { oferuje nowe treści. }\end{array}$ & $\begin{array}{l}\text { Sieć społecznościowa } \\
\text { utrzymuje w ten spo- } \\
\text { sób zainteresowanie } \\
\text { i chęć przebywania na } \\
\text { portalu. }\end{array}$ & $\begin{array}{l}\text { Im dłużej użytkownik } \\
\text { korzysta z danej sieci } \\
\text { społecznościowej, tym } \\
\text { więcej reklam zobaczy, } \\
\text { co przekłada się na zy- } \\
\text { ski operatora portalu. }\end{array}$ \\
\hline $\begin{array}{l}\text { Możliwość } \\
\text { łatwego znale- } \\
\text { zienia nowych } \\
\text { kontaktów }\end{array}$ & $\begin{array}{l}\text { Użytkownik może ła- } \\
\text { two nawiązać nowe } \\
\text { znajomości lub odszu- } \\
\text { kać osoby poznane } \\
\text { wcześniej. }\end{array}$ & $\begin{array}{l}\text { Sieć społecznościo- } \\
\text { wa przyciaga nowych } \\
\text { użytkowników na za- } \\
\text { sadzie efektu kuli śnie- } \\
\text { gowej. }\end{array}$ & $\begin{array}{l}\text { Liczba użytkowników } \\
\text { stanowi istotną prze- } \\
\text { wage konkurencyjną, } \\
\text { ponieważ daje użyt- } \\
\text { kownikom większe } \\
\text { szanse na znalezienie } \\
\text { konkretnej osoby. }\end{array}$ \\
\hline Brak opłat & $\begin{array}{l}\text { Użytkownik może } \\
\text { spróbować bez ryzyka, } \\
\text { czy serwis społeczno- } \\
\text { ściowy mu odpowiada. }\end{array}$ & $\begin{array}{l}\text { Okres próbny zwykle } \\
\text { przeradza się w długo- } \\
\text { trwałe użytkowanie. }\end{array}$ & - \\
\hline
\end{tabular}

Źródło: opracowanie własne.

Tabela 3 ilustruje, jakie korzyści otrzymuje użytkownik i operator sieci społecznościowej z oferowania produktu, który jest dostępny dla wszystkich konsumentów na rynku, bez dodatkowych opłat. Facebook jest firmą oferującą usługi komunikacyjne, ale tak naprawdę to usługi reklamowe są podsta- 
wowym źródłem dochodu ${ }^{38}$. Sieć społecznościowa w swoich dokumentach finansowych ${ }^{39}$ wskazuje, że pojedynczy użytkownik był wart w czwartym kwartale 2020 r. około 10,14 dolara amerykańskiego. Należy także zwrócić uwagę, że firma Facebook jest notowana na amerykańskiej giełdzie papierów wartościowych, stąd jej działalność jest przedmiotem oceny ze strony inwestorów oraz szerokiej opinii publicznej. Zarząd natomiast musi tak kierować firmą, by wartość akcji utrzymywała się na stabilnym wysokim poziomie, co niejako wymusza działania, które przełożą się na wzrost przychodów firmy. Ideały i chęć połączenia świata musi ustąpić logice finansowej. Facebook jest sterowany przez algorytmy, które zostały zaprogramowane, aby zatrzymać użytkownika przed ekranem, wywołać reakcjęi w konsekwencji zwiększyć zaangażowanie na platformie $e^{40}$. Im większe zaangażowanie, tym więcej danych otrzymuje algorytm, by jeszcze lepiej dopasowywać nowe treści i reklamy do preferencji użytkownika. W tym miejscu należy postawić pytanie o podmiotowość wspomnianego użytkownika i odpowiedzialność platformy społecznościowej za wyświetlane treści. W roku 2018 Mark Zuckerberg, założyciel i prezes Facebooka, zeznając przed Komisją ds. Energii i Handlu Kongresu Stanów Zjednoczonych, powiedział, że Facebook jest firmą technologiczną, nie należy do sektora medió ${ }^{41}$. Jest to istotne stwierdzenie, ponieważ oznacza to, że firma nie podlega takiej samej kontroli w zakresie publikowania treści oraz wyświetlania reklam, jak telewizja, radio czy prasa. Mając jednak 75\% przewagi na rynku platform społecznościowych pod względem liczby użytkowników, dla wielu z nich Facebook jest podstawowym źródłem informacji. Badania przeprowadzone przez Pew Research Center we wrześniu $2020 \mathrm{r}^{42}$ wskazały, że 53\% Amerykanów często poszukuje wiadomości na platformach społecznościowych, a na pierwszym miejscu znalazł się właśnie Facebook. Podstawowy problem polega tu na sprzeczności interesów: $\mathrm{z}$ jednej strony firma chce łączyć ludzi i dostarczać wartościowe treści; z drugiej

38 S. Rodriguez, Facebook Earnings Beat but the Company Warns of Impact From Apple Privacy Changes, CNBC, https://www.cnbc.com/2021/01/27/facebook-fb-earnings-q4-2020.html (dostęp: 19.07.2021).

39 Ibidem.

40 L. Andrews, Facebook, the Media and Democracy: Big Tech, Small State?, New York 2019.

${ }^{41}$ M. Castillo, Zuckerberg Tells Congress Facebook is Not a Media Company: 'I consider us to be a Technology Company', CNBC, https://www.cnbc.com/2018/04/11/mark-zuckerberg-facebook-is-a-technology-company-not-media-company.html (dostęp: 19.07.2021).

42 News Use Across Social Media Platforms in 2020, Pew Research Center, https://www. journalism.org/2021/01/12/news-use-across-social-media-platforms-in-2020/ (dostęp: 19.07.2021). 
zaś jest zobligowana przez swoich akcjonariuszy do maksymalizowania zysków. Algorytmy natomiast na bieżąco analizują poczynania każdego użytkownika i dostarczają nowych treści, które będą z jego punktu widzenia interesujące. Interesujące to znaczy takie, które wywołają reakcję z jego strony, a tym samym przedłużą interakcję z platformą społecznościową. A wszystko to odbywa się poza kontrolą ze strony instytucji państwowych. Wspomniane wcześniej przesłuchanie Marka Zuckerberga dotyczyło związków firmy Facebook z firmą Cambridge Analytica, która otrzymała nieuprawniony dostęp do danych osobowych 87 milionów użytkowników platformy ${ }^{43}$. Mark Zuckerberg $\mathrm{w}$ trakcie przesłuchania przed amerykańskim Kongresem przyznał, że firma nie dołożyła należytej staranności, jeśli chodzi o ochronę prywatności użytkowników. Obiecał także szczegółowe dochodzenie w zakresie, jakie aplikacje mają dostęp do danych na platformie oraz wprowadzenie szeregu rozwiązań chroniących prywatność użytkowników. Stwierdzenia te były jednak bardzo ogólne i trudno zweryfikować, co faktycznie się zmieniło ${ }^{44}$. Facebook w 2020 r. udostępnił narzędzia pozwalające zobaczyć, skąd portal zbiera dane, w tym także identyfikujące źródła poza siecią społecznościową ${ }^{45}$. Pozwala ono także na usuwanie tych danych, jednak nie ma możliwości całkowitego zablokowania zbierania danych w przyszłości. Na tym polu dość znaczącym sukcesem okazały się działania firmy Apple, która wraz z aktualizacją iOS 14.5 wprowadziła narzędzie App Tracking Transparency ${ }^{46}$, które pozwala zablokować zbieranie danych przez aplikację zainstalowaną w smartfonie lub tablecie ${ }^{47}$. Przy pierwszym uruchomieniu aplikacji urządzenie pyta użytkownika, czy ten zgadza się, aby aplikacja zbierała o nim dane. Szacun-

43 S. Salinas, Facebook Says the Number of Users Affected by Cambridge Analytica Data Leak is 87 million, CNBC, https://www.cnbc.com/2018/04/04/facebook-updates-the-number-of-users-impacted-by-cambridge-analytica-leak-to-87-million-.html (dostęp: 19.07.2021).

44 J. C. Wong, The Cambridge Analytica Scandal Changed the World - but It Didn't Change Facebook, „The Guardian”, https://www.theguardian.com/technology/2019/mar/17/ the-cambridge-analytica-scandal-changed-the-world-but-it-didnt-change-facebook (dostęp: 19.07.2021).

45 L. Dami, Facebook's Clear History Tool is Now Available to Everyone, „The Verge”, https:// www.theverge.com/2020/1/28/21111981/facebooks-clear-history-tool-now-available-to-everyone (dostęp: 19.07.2021).

46 Transparentność w zakresie aplikacji śledzących - tłumaczenie własne autora.

47 M. Karbowiak, Facebook vs Apple: Szczegóły sporu o nowe narzędzie do blokowania śledzenia użytkownika $w$ systemie iOS 14.5, https://www.purepc.pl/facebook-vs-apple-szczegoly-sporu-o-nowe-narzedzie-do-blokowania-sledzenia-uzytkownika-w-systemie-ios-14-5 (dostęp: 19.07.2021). 
ki wskazują, że zaledwie 12\% użytkowników wyraziło zgodę ${ }^{48}$. Elementem wyróżniającym to rozwiązanie względem narzędzi oferowanych przez Facebooka jest jego prostota oraz łatwość użycia. Użytkownik przy pierwszym uruchomieniu aplikacji zawierającej komponent śledzący otrzymuje pytanie. Udzielenie odpowiedzi jest konieczne, inaczej aplikacja się nie uruchomi. Ustawienia prywatności Facebooka natomiast znajdują się w opcjach aplikacji, stąd aby do nich dotrzeć, trzeba wykonać pewną dodatkową pracę. Co więcej, Facebook domyślnie zakłada, że użytkowcy zgadzają się na zbieranie informacji o nich, więc to na nich spoczywa obowiązek wyłączenia poszczególnych opcji. Jest to przykład działań pozorowanych, mających pokazać opinii publicznej, że firma wykonała pewne działania, aniżeli faktyczną zmianę obecnej sytuacji.

\section{Globalne korporacje wyznaczają standardy}

Powyższy przykład ilustruje, jak wielką siłę oddziaływania mają globalne korporacje, które ustanawiają standardy funkcjonowania wedle własnego uznania, wymuszając na swoich użytkownikach przyjęcie nowych reguł. Facebook, pomimo działań ze strony władz amerykańskich, nie dokonał znaczących zmian w zakresie ochrony prywatności, choć wprowadzone narzędzia należy uznać za krok we właściwym kierunku. Dopiero firma Apple, globalna korporacja, była w stanie realnie zmienić sytuację i wywołać silną reakcję ze strony najpopularniejszej platformy społecznościowej ${ }^{49}$. Warto w tym miejscu spojrzeć na firmę Google - właściciela najpopularniejszej wyszukiwarki internetowej oraz serwisu $\mathrm{z}$ materiałami wideo na żądanie. Podobnie jak Facebook, Google jest liderem we wspomnianych kategoriach i oferuje swoje usługi użytkownikom prywatnym bez dodatkowych opłat. Dane z czerwca $2021 \mathrm{r}$. wskazują, że wyszukiwarka Google obsługuje ponad 90\% użytkowników na świecie ${ }^{50}$. Na drugim miejscu znajduje się wyszukiwarka Bing firmy Microsoft obsługująca nieco ponad 2\%. Obraz sytuacji dopełniają statystyki rynku

48 T. Hardwick, Analytics Suggest 96\% of Users Leave App Tracking Disabled in iOS 14.5, MacRumors, https:/www.macrumors.com/2021/05/07/most-iphone-users-app-tracking-opt-out/ (dostęp: 19.07.2021).

49 Facebook w sprawozdaniu finansowym ostrzega, że działania firmy Apple mogą spowodować spadek dochodów firmy w drugim kwartale 2021 r. S. Dang, Apple iPhone Privacy Update Seen Hurting Facebook Revenue in Q2, https://www.reuters.com/technology/apple-iphone-privacy-update-seen-hurting-facebook-revenue-q2-2021-04-26/ (dostęp: 19.07.2021).

50 Search Engine Market Share Worldwide, „Statcounter. Global Stats”, https://gs.statcounter.com/search-engine-market-share (dostęp: 19.07.2021). 
przeglądarek internetowych, gdzie Chrome, produkt omawianej firmy, jest na pierwszym miejscu $\mathrm{z}$ wynikiem ponad $65 \%$. Oznacza to, że ponad $65 \%$ internautów na świecie korzysta $\mathrm{z}$ tej przeglądarki na co dzień, natomiast największy konkurent - Safari od firmy Apple zajmuje nieco ponad 18\% rynku. Tym samym firma Google posiada szeroką wiedzę na temat, czym interesują się internauci na świecie i jakich informacji szukają. Przy tak dużej przewadze nad konkurencją korporacja ma dostatecznie dużą siłę przetargową, by kreować standardy związane z przesyłaniem danych w Internecie czy optymalizowaniem stron internetowych pod kątem wyszukiwarek, co ma istotne znaczenie w marketingu internetowym. Przykład użycia wspomnianej siły przetargowej można było zaobserwować na początku tego roku, gdy firma Google zaproponowała nowy mechanizm przechowywania danych użytkownika w przeglądarce o nazwie $\mathrm{FLoC}^{51}$. W teorii miał on zastąpić używane dotychczas ciasteczka w przeglądarce mechanizmem, który przechowywałby wszystkie dane w przeglądarce i nie wysyłałby ich na zewnątrz ${ }^{52}$. Przeglądarka (a ściślej algorytm zainstalowany w jej ramach) byłaby odpowiedzialna za stworzenie profilu użytkownika i wysłanie tych danych do reklamodawców w formie zanonimizowanej. Osoba byłaby przyporządkowana do pewnej grupy osób, np. lubiących dany produkt, a nie traktowana jako identyfikowalna jednostka. W teorii zmniejsza to ryzyko wycieku danych oraz ogranicza ewentualne nadużycia. Obecnie śledzenie aktywności użytkowników odbywa się za pomocą plików cookie (ciasteczek), gdzie każdy reklamodawca instaluje własne i sam reguluje, jak długo mogą one funkcjonować na naszym urządzeniu. Jeżeli spojrzeć na problem tylko z perspektywy prywatności użytkownika, to FLoC jest dobrym rozwiązaniem ${ }^{53}$. Należy jednak zwrócić uwagę, że jest to projekt autorstwa firmy Google, która dominuje w sferze wyszukiwania i przeglądarek internetowych. Jeżeli przeforsowano by tę zmianę, firma miałaby znaczną kontrolę nad danymi o użytkownikach Internetu oraz marketingiem internetowym w szerokim rozumieniu tego pojęcia. Google mogłoby arbitralnie narzucać zmiany, a niezależni reklamodawcy musieliby się dostosować. W obliczu znaczącej krytyki ze strony przemysłu komputerowego oraz deklaracji ze strony pozostałych producentów przeglądarek internetowych, że będą aktywnie blokować nowe rozwiązanie, Google podjęło decyzję, że wstrzyma jego

51 FLoC to skrót od Federated Learning of Cohorts, co można przetłumaczyć jako wspólne uczenie się i grupowanie użytkowników w zespoły (kohorty).

52 M. Lewk, Ewolucja prywatności w przeglądarkach: Federated Learning of Cohorts (FLoC), „Nowy Marketing”, https://nowymarketing.pl/a/32370, ewolucja-prywatnosci-w-przegladarkach-federated-learning-of-cohorts-floc (dostęp: 19.07.2021).

53 Ch. Bindra, Building a privacy-first future for web advertising, Google Ads, https://blog. google/products/ads-commerce/2021-01-privacy-sandbox/ (dostęp: 30.07.2021). 
wprowadzenie do $2023 \mathrm{r}^{54}$ Jest to kolejny przykład, gdzie presja innych podmiotów globalnych wymusiła zmianę zachowania dużej korporacji, co nie oznacza, że Google nie będzie forsować tego rozwiązania w przyszłości. To pokazuje, jak dużym zagrożeniem mogą być globalne korporacje, które zdominowały pewien fragment rynku, istotny z punktu widzenia nowoczesnej gospodarki. Naturalnie możliwe jest funkcjonowanie w nowoczesnym świecie bez posiadania konta na Facebooku, jednak szczególnie podczas globalnej pandemii stanowi to realne utrudnienie. Alternatywne rozwiązania istnieją, lecz nie oferują tak szerokiego wachlarza korzyści. Jest to szczególnie widoczne w przypadku wyszukiwarki internetowej Google, która dzięki olbrzymiej ilości danych i obsługiwanych zapytań jest w stanie lepiej dopasować wyniki do oczekiwań odbiorcy. Ceną, jaką płaci za to użytkownik, jest jego prywatność, która wydaje się być wprost proporcjonalna do użyteczności produktu: im więcej danych użytkownik udostępni, tym lepszej jakości otrzymuje usługę. Pytanie, czy ta wymiana jest faktycznie opłacalna, pozostaje otwarte.

\section{Podsumowanie}

Celem artykułu było wskazanie zagrożeń dla prywatności użytkowników w Internecie, jakie płyną z dominacji jednej globalnej korporacji w danym sektorze usług, Facebook i Google, które oferują swoje usługi w Internecie, nie pobierając opłat od konsumentów. Ceną jest tutaj prywatność i konieczność dzielenia się swoimi danymi ze wspominanymi korporacjami, które później wykorzystują te dane do budowania spersonalizowanych kampanii marketingowych. Siła przetargowa tych firm jest wystarczająca, by proponować standardy i zmiany, które dotykają szeroko pojętego Internetu. W konsekwencji sieć globalna, która miała być najbardziej demokratycznym z mediów, jest zarządzana przez pojedyncze globalne firmy, które decydują o tym, co dany użytkownik zobaczy, a co zostanie przemilczane. Jak pokazały przesłuchania Marka Zuckerberga z 2018 r., demokratyczna władza, która powinna sprawować kontrolę nad funkcjonowaniem gospodarki, w praktyce okazała się bezradna. Firma Google stoi w obliczu oskarżeń o praktyki monopolistyczne i utrudnianie działalności konkurencyjnym firmom. Oskarżenia te płyną zarówno ze strony administracji Stanów Zjednoczonych, jak i Unii Europejskiej ${ }^{55}$. Trudno w tym momencie

54 R. Amadeo, Google delays FLoC rollout until 2023, https://arstechnica.com/gadgets/2021/06/google-delays-floc-rollout-until-2023/ (dostęp: 19.07.2021).

55 L. Feiner, Google's Antitrust Mess: Here Are All the Major Cases It's Facing in the U.S. and Europe, CNBC, https://www.cnbc.com/2020/12/18/google-antitrust-cases-in-us-and-europe-overview.html (dostęp: 19.07.2021). 
ocenić, jaki będzie skutek tych działań, jednak bazując na wcześniejszych karach finansowych, wymierzonych firmie przez Komisję Europejską ${ }^{56}$, nie należy spodziewać się znaczącej zmiany. Z punktu widzenia użytkowników pozytywną zmianą jest wprowadzenie przez obie firmy narzędzi pozwalających sprawdzić, jakimi danymi dysponują firmy oraz nakazać ich usunięcie. Nie chroni to przed dalszym śledzeniem aktywności w Internecie, lecz ogranicza ewentualne negatywne skutki. Pandemia pokazała, że narzędzia internetowe są niezbędne w codziennym życiu i dzięki takim usługom jak Facebook czy wyszukiwarka Google wiele osób mogło dalej kontynuować pracę i naukę zdalnie oraz utrzymywać kontakt z bliskimi. Jednocześnie uwypukliło to fakt, że globalne korporacje dysponują olbrzymią siłą oddziaływania na gospodarkę światową oraz na pojedyncze osoby. Jest to temat wymagający dalszej analizy, szczególnie z perspektywy relacji pomiędzy biznesem globalnym a władzami poszczególnych państw czy też instytucji ponadnarodowych.

\section{Bibliografia}

Amadeo R., Google delays FLoC rollout until 2023, https://arstechnica.com/gadgets/2021/06/google-delays-floc-rollout-until-2023/ (dostęp: 19.07.2021).

Andrews L., Facebook, the Media and Democracy: Big Tech, Small State?, New York 2019.

Ang C., One Year In: Data Usage Surged During Pandemic, „Visual Capitalist”, https://www.visualcapitalist.com/data-usage-surged-during-pandemic/ (dostęp: 12.07.2021).

Antitrust: Commission fines Google $€ 1.49$ billion for abusive practices in online advertising, European Comission, https://ec.europa.eu/commission/ presscorner/detail/en/IP_19_1770 (dostęp: 13.07.2021).

Arrington M., Facebook No Longer The Second Largest Social Network, „TechCrunch", https://techcrunch.com/2008/06/12/facebook-no-longer-the-second-largest-social-network/ (dostęp: 13.07.2021).

Blanke T., Digital Asset Ecosystems: Rethinking Crowds and Clouds, Kidlington 2014.

Burgess J., Baym N. K., Twitter: A Biography, New York 2020.

Castillo M., Zuckerberg Tells Congress Facebook Is Not a Media Company: 'I consider us to be a Technology Company', CNBC, https://www.cnbc.

56 Antitrust: Commission fines Google $€ 1.49$ billion for abusive practices in online advertising, European Comission, https://ec.europa.eu/commission/presscorner/detail/en/ IP_19_1770 (dostęp: 19.07.2021). 
com/2018/04/11/mark-zuckerberg-facebook-is-a-technology-company-not-media-company.html (dostęp: 19.07.2021).

Change in remote work trends due to COVID-19 in the United States in 2020, Statista, https://www.statista.com/statistics/1122987/change-in-remote-work-trends-after-covid-in-usa/ (dostęp: 8.07.2021).

Dami L., Facebook's Clear History Tool Is Now Available to Everyone, „The Verge”, https://www.theverge.com/2020/1/28/21111981/facebooks-clear-history-tool-now-available-to-everyone (dostęp: 19.07.2021).

Dang S., Apple iPhone Privacy Update Seen Hurting Facebook Revenue in Q2, https://www.reuters.com/technology/apple-iphone-privacy-update-seen-hurting-facebook-revenue-q2-2021-04-26/ (dostęp: 19.07.2021).

De Saulles M., The Internet of Things and Business, New York 2017.

Deutsch A. L., WhatsApp: The Best Facebook Purchase Ever?, „Investopedia”, https://www.investopedia.com/articles/investing/032515/whatsapp-best-facebook-purchase-ever.asp (dostęp: 13.07.2021).

Digital 2021. We are social, https://wearesocial.com/digital-2021 (dostęp: 13.07.2021).

Feiner L., Google's Antitrust Mess: Here Are All the Major Cases It's Facing in the U.S. and Europe, CNBC, https://www.cnbc.com/2020/12/18/google-antitrust-cases-in-us-and-europe-overview.html (dostęp: 19.07.2021).

Grover R., Vriens M., The Handbook of Marketing Research: Uses, Misuses, and Future Advances, London 2006.

Grzegorzewska M., Miliard czy milion - liczba użytkowników Google, „SternaSEO”, https://sternaseo.pl/miliard-czy-milion-liczba-uzytkownikow-google/ (dostęp: 8.07.2021).

GUS: w 2020 r. Internet najpopularniejszym źródłem informacji o COVID-19, „Polsat News”, https://www.polsatnews.pl/wiadomosc/2021-03-11/gus-w-2020-r-internet-najpopularniejszym-zrodlem-informacji-o-covid-19/ (dostęp: 11.07.2021).

Hardwick T., Analytics Suggest 96\% of Users Leave App Tracking Disabled in iOS 14.5, „MacRumors”, https://www.macrumors.com/2021/05/07/most-iphone-users-app-tracking-opt-out/ (dostęp: 19.07.2021).

Hutchinson A., What Does Facebook Know About You Really?, „Social Media Today", https://www.socialmediatoday.com/news/what-does-facebook-know-about-you-really/546502/ (dostęp: 16.07.2021).

Jak Polacy korzystaja $z$ internetu? Oto raport $z 2021$ roku!, „Funkymedia”, https://funkymedia.pl/jak-polacy-korzystaja-z-internetu-oto-raport-z-2021-roku.html (dostęp: 13.07.2021).

Jemielniak D., Socjologia internetu, Warszawa 2019. 
Kaplan A. M., Haenlein M., Users of the World, Unite! The Challenges and Opportunities of Social Media, „Business Horizons” 2010, t. 53.

Karbowiak M., Facebook vs Apple: Szczegóty sporu o nowe narzędzie do blokowania śledzenia użytkownika w systemie iOS 14.5, https://www.purepc. pl/facebook-vs-apple-szczegoly-sporu-o-nowe-narzedzie-do-blokowania-sledzenia-uzytkownika-w-systemie-ios-14-5 (dostęp: 19.07.2021).

Kemp S., Digital 2021: Poland, https://datareportal.com/reports/digital-2021poland?rq=poland (dostęp: 13.07.2021).

Kincaid J., Facebook Launches Standalone iPhone/Android Messenger App, „TechCrunch”, https://techcrunch.com/2011/08/09/facebook-launches-standalone-mobile-messenger-app-and-it\%E2\%80\%99s-beluga/ (dostęp: 13.07.2021).

Korzystanie $z$ internetu. Komunikat $z$ badań, CBOS, https://www.cbos.pl/SPISKOM.POL/ 2020/K_085_20.PDF (dostęp: 13.07.2021).

Kumar V., Reinartz W., Customer Relationship Management: Concept, Strategy, and Tools, Bamberg 2018.

Lewk M., Ewolucja prywatności w przeglądarkach: Federated Learning of Cohorts (FLoC), „Nowy Marketing”, https://nowymarketing.pl/a/32370,ewolucja-prywatnosci-w-przegladarkach-federated-learning-of-cohorts-floc (dostęp: 19.07.2021).

Miller D., Costa E., McDonald T., Nicolescu R., Sinanan J., Spyer J., Venkatraman S., Wang X., How the World Changed Social Media, London 2016.

Miller M., Facebook for Grown-ups, Hoboken 2010.

News Use Across Social Media Platforms in 2020, Pew Research Center, https:// www.journalism.org/2021/01/12/news-use-across-social-media-platforms-in-2020/ (dostęp: 19.07.2021).

O'Flaherty K., All the Ways Facebook Tracks You and How to Stop It, „Forbes”, https://www.forbes.com/sites/kateoflahertyuk/2021/05/08/all-the-ways-facebook-tracks-you-and-how-to-stop-it/ (dostęp: 6.07.2021).

OECD, Digital Transformation in the Age of COVID-19: Building Resilience and Bridging Divides, „Digital Economy Outlook 2020 Supplement”, www. oecd.org/digital/digital-economy-outlook-covid.pdf (dostęp: 11.07.2021).

Osenton T., Customer Share Marketing: How the World's Great Marketers Unlock Profits from Customer Loyalty, FT Press, New Jersey 2002.

Penc-Pietrzak I., Planowanie strategiczne w nowoczesnej firmie, Warszawa 2010. Piechocki W., Polskie sieci komórkowe obsługuja rekordowe ilości przesyłanych danych - jesteśmy w europejskiej czołówce, GSMOnline.pl, https://gsmonline.pl/artykuly/ruch-danych-sieci-komorkowe-europa-polska (dostęp: 13.07.2021). 
Piksel Facebooka, Facebook for Business, https://www.facebook.com/business/ help/742478679120153?id=1205376682832142 (dostęp: 16.07.2021).

Rizzo L., Click S., How Covid-19 Changed Americans' Internet Habits, „The Wall Street Journal", https://www.wsj.com/articles/coronavirus-lockdown-tested-internets-backbone-11597503600 (dostęp: 11.07.2021).

Rodriguez S., As Calls Grow to Split up Facebook, employees who Were There for the Instagram Acquisition Explain Why the Deal Happened, CNBC, https:// www.cnbc.com/2019/09/24/facebook-bought-instagram-because-it-was-scared-of-twitter-and-google.html (dostęp: 13.07.2021).

Rodriguez S., Facebook Earnings Beat but the Company Warns of Impact from Apple Privacy Changes, CNBC, https://www.cnbc.com/2021/01/27/facebook-fb-earnings-q4-2020.html (dostęp: 19.07.2021).

Salinas S., Facebook Says the Number of Users Affected by Cambridge Analytica Data Leak is 87 million, CNBC, https://www.cnbc.com/2018/04/04/ facebook-updates-the-number-of-users-impacted-by-cambridge-analytica-leak-to-87-million-.html (dostęp: 19.07.2021).

Slikowski K., Microsoft Teams ma już 145 milionów aktywnych użytkowników dziennie, „CentrumXP”, https://www.centrumxp.pl/Publikacja/Microsoft-Teams-ma-juz-145-milionow-aktywnych-uzytkownikow-dziennie (dostęp: 8.07.2021).

Social Media Stats Worldwide, Statcounter GlobalStats, https://gs.statcounter. com/social-media-stats (dostęp: 13.07.2021).

Społeczeństwo informacyjne w Polsce w 2020 r., Główny Urząd Statystyczny, https://stat.gov.pl/download/gfx/portalinformacyjny/pl/defaultaktualnosci/5497/2/10/1/spoleczenstwo_informacyjne_w_polsce_w_2020.pdf (dostęp: 11.07.2021).

Taylor D. B., A Timeline of the Coronavirus Pandemic, „New York Times”, https:// www.nytimes.com/article/coronavirus-timeline.html (dostęp: 9.07.2021).

Telework in the EU before and after the COVID-19: where we were, where we head to, Science for Policy Briefs, https://ec.europa.eu/jrc/sites/default/ files/jrc120945_policy_brief_-_covid_and_telework_final.pdf (dostęp: 8.07.2021).

Wong J. C., The Cambridge Analytica Scandal Changed the World - But It Didn't Change Facebook, „The Guardian”, https://www.theguardian.com/techno$\log / 2019 / \mathrm{mar} / 17 /$ the-cambridge-analytica-scandal-changed-the-world-but-it-didnt-change-facebook (dostęp: 19.07.2021).

Żuławiński M., Zoom przeżywa boom. Wideokonferencje warte więcej niż linie lotnicze, „Bankier.pl”, https://www.bankier.pl/wiadomosc/Zoom-przezywa-boom-Wideokonferencje-warte-wiecej-niz-linie-lotnicze-7886776. html (dostęp: 8.07.2021). 